UDC 339.138:659.18:330.161

JEL Classification M37, L8, P16

Ischenko I.O., Smiesova V.L.

\title{
THE MAIN APPROACHES TO THE USE OF INTERNET MARKETING AND ADVERTISING OFFLINE AS A REFLECTION OF THE INTERESTS OF THE SUBJECTS OF ADVERTISING RELATIONS
}

\author{
Ukrainian State University of Chemical Technology, Dnipro, Ukraine
}

\begin{abstract}
The article is devoted to the development of basic approaches to the use of Internet marketing tools in order to meet the interests of the subjects of advertising relations. The main approaches to advertising various product groups in the Internet space are considered depending on the target audience. Analyzed the strengths and weaknesses of online and offline advertising. A comparison of various Internet marketing tools was carried out - the creation of Web sites for the presentation and promotion of their products and services, Email marketing, viral marketing. Considered the economic interests of each of the parties of the advertising relationship. A new economic category "symbion" is proposed, which is understood as a form of advertising relationship in which potential advertising customers meet their interests with an active combination of offline advertising with Internet advertising. The main economic results of the interaction of offline advertising with Internet advertising are substantiated. New advertising tools are offered - collection of individual information about their users and personalized advertising, neuromarketing. A matrix-forecast of the main marketing approaches has been developed and presented, which can be used in advertising the main types of product groups depending on the age audience - for the categories "youth", "middle-aged people", and "pensioners".
\end{abstract}

Keywords: E-mail marketing, viral marketing, Internet advertising, personalized advertising, neuromarketing, online advertising, offline advertising, economic interests, advertising relations.

DOI: $10.32434 / 2415-3974-2018-8-2-120-124$

\section{Introduction}

In today's world, we are faced with advertising every day. It firmly and quietly entered the life of every person, whether he wants it or not. As a phenomenon, advertising originated long before the birth of Christ and was used for certain types of financial services and trade, and today the advantages of advertising are successfully used by most economic actors in all spheres of economic activity. Even in ancient Egypt, slavers wrote on papyrus the first in the history of mankind advertising texts about the sale of slaves. A little later, in Rome and ancient Greece, ads and propaganda texts began to carve on wax and wooden plates. So the first offline advertising was born. With the development of handicrafts, each master sought to put on his product a label or stamp, by which it could be easily recognized. In the modern world, every self-respecting company or company also has its own slogan and trademark. All this suggests that humanity has long come to a simple truth - advertising is the engine of commerce.

\section{Analysis and research of publications}

Modern economists are conducting research in the field of shaping marketing approaches to advertising goods - in the area of analyzing the main problems and prospects for the development of Internet marketing in Ukraine (Kuznetsova N.) [1], elements of its concept, basic tools, advantages for domestic enterprises (Lyashenko G.P., Motkalyuk R.V., Mozgova G.V.) [2,3], its advantages and disadvantages (Sydenko Y.V.) [4].

At the same time, practical economic activity raises important questions for producers of goods and services. What kind of advertising will be the most acceptable in one way or another for a particular product? What constumers will respond to this ad? How to find a consumer who will be interested in this product? And vice versa - how can advertising cause the consumer to buy goods? What marketing strategy needs to be applied in order to maximize sales and profits? The key to solving the problems posed, from our point of view, lies in the development 
of the forecast of the most optimal types of marketing and advertising while promoting the main types of product groups.

Therefore, the purpose of this article is to substantiate the main marketing approaches that can be used in advertising the main types of product groups, based on the characteristics of the target audience; determining the benefits of using innovative technologies of advertising on the Internet for subjects of economic relations.

\section{Main results}

All modern advertising can be divided into two types: offline advertising and Internet marketing. Such forms as cold calls, print advertising in magazines and newspapers, as well as all types of outdoor advertising, SMS-mailing, television and radio advertising, advertising in transport, business seminars, word of mouth, etc. [5].

One of the main problems of offline product promotion is its relatively high cost compared to Internet advertising. The financial costs of implementing the above strategies are several orders of magnitude higher than the cost of advertising on the Internet; they require the collection and analysis of additional information by the companiescustomers of their potential clients, their interests and preferences. This also implies additional time spent on identifying the direction of consumer interests.

Therefore, producer entities or advertising agencies representing their interests, it is necessary to carry out an in-depth analysis in order to understand which marketing strategy is suitable for a particular target audience. The advertiser on the basis of expert opinion must calculate the smallest amount of financial costs that are necessary for effective advertising. And the main criterion for evaluating his work on the development of offline advertising is the increase in net profit from advertising as the difference between the increase in revenues and costs minus the cost of an advertising campaign.

Offline advertising has both its pros and cons. The advantages include: 1 ) the possibility of reaching a huge target audience during television and radio broadcasts; 2) unobtrusiveness for potential consumers; 3 ) the ability to adjust advertising texts based on geographic location; 4) viewing outdoor advertising by people who do not have access to media broadcasts; 5) the possibility of visual examination of goods at exhibitions and fairs; 6) an increase in the status of an ad in the case of an advertising company on the pages of popular newspapers and magazines, etc.

The disadvantages include the lack of visual contact on radio broadcasts, the static nature of advertisements on billboards, the lack of selectivity of the target audience, a large time lag between the preparation of advertising information and its publication in newspapers and magazines. All this makes it extremely difficult to assess the costeffectiveness of offline advertising.

Online marketing works in a different way. Companies create Web sites for the presentation and promotion of their products and services. With their skillful and competent content, availability of information for a potential consumer, the simplicity of its location and visual attractiveness, websites ensure that product owners can effectively compete with other companies producing similar products, guarantee a high level of sales and a steady income. This means that they directly ensure the satisfaction of their economic interests, contribute to the formation of economic relations with potential consumers and their subsequent reproduction.

Another type of online marketing is E-mail marketing. With the help of special programs, this marketing technology allows you to send advertising information to e-mail potential buyers. In this case, the advertising company will be directed to a specific person and with the help of feedback it will be possible to find out his reaction to the received advertising information, to determine, firstly, the circle of consumers who do not want to receive such a newsletter, and therefore are focused on another type of advertising secondly, to identify those entities that it suits, to analyze their interests and needs [6].

Also one of the tools of online marketing is viral marketing, when using spa programs, advertising information is disseminated in an attractive form in the form of cartoons, music videos, and scandalous and sharp scandals. The positive aspects of this type of advertising strategy include the lack of costs for the transmission of viral advertising, the possibility of its continued use, a high degree of trust. Weaknesses of Internet marketing are frequent fraud in the Internet space, dependence on electronic payment systems (stability of their work, availability and amount of commission for their use, the need for a potential buyer to specify their personal data, accounts and secret codes), the inability to reach those segments of the population that do not have access to the Internet, the limited prediction of the amount of potential profit, etc. [6].

An important point in choosing the type of advertising strategy (Internet or offline marketing) is taking into account the target audience, the type of product that is planned to be implemented, as well as a clear identification of the functions and role of each participant in the chain of relations "customer - advertiser - consumer". The manufacturer as a customer of an advertising product is interested in increasing the sales of its original products, increasing sales and maximizing its economic interests. Ensuring the realization of the interests of the advertiser primarily depends on 
whether he can convey advertising information to a wide range of consumers, which will determine the effectiveness of advertising, and therefore the effectiveness of its activities. Consumers are primarily interested in goods with an optimal ratio of pricequality characteristics, an affordable price, and minimum delivery times. Therefore, even counterfeit products, which are characterized by low quality and cost, can cause their interest.

In this scenario, the interests of market actors - both Internet and offline marketing can face unpredictable consumer behavior. Given the growth in the number and range of counterfeit products on the market, especially in such areas as consumer goods production and pharmaceuticals, both types of marketing will not bring the expected result to bona fide producers, because the largest consumer segment (poor and middle class) always will focus on a cheaper product.

One of the currently effective marketing technologies that restrict the advertising of counterfeit products are blockchain technology, which is effectively used as a platform to support cryptocurrency. Its advantages are: 1 ) the availability of the technology algorithm code; 2) confidentiality, that is, the ability to enter into any financial transactions from your crypto wallet without disclosing your personal data; 3 ) security of personal cryptographic security before cyber fraud; 4) universality - independence from various banks of other financial structures that control transactions [7].

This gives a good reason to consider Internet marketing as an effective tool for advertising and selling original products of bona fide manufacturers.

In our opinion, by 2020, to maximize consumer incentives, there will be a need for a simbione of offline advertising and online marketing.

Under the category of «symbion» we understand the form of advertising relationships in which potential advertising customers meet their interests with the active combination of offline advertising with Internet advertising. The latter complement and complement organically interact, intertwine and penetrate into each other, forming a single whole an advertising product. The main positive results of such a symbiotic interaction will be: maximum coverage of the target audience - consumers of both old and young and middle age, both in the Internet space and outside of it, as consumers with visual perception, and consumers trusting proven and reliable information; realization of the interests of the entire range of participants in marketing relations - consumers, customers and performers of advertising; a significant reduction in advertising costs due to the use of the same advertising, reducing the cost of advertising through a free Internet service, etc.
Advertising companies need to develop technologies that can provide a combination of only the best of both types of marketing strategies. Even today, the latest high technology marketing technologies are actively beginning to use in the advertising market. In particular, in Internet marketing, this is primarily the collection of individual information about its users; in offline marketing, this is neuromarketing technology.

The collection of individual information is based on cookies or similar programs that make it possible to send short text files to browsers. The latter, in turn, allow you to save information about visits and preferences of visitors. For example, on the individual choice of the language of communication and other settings. This allows the subsequent visit to the site to direct the visitor to the most appropriate web pages for him.

Neuromarketing involves the collection of information based on the study of objective indirect reactions of the consumer. Such verbal information can be obtained only through the personal contact of the interviewer with a potential consumer, the correct formulation of questions that should be acceptable and should not cross certain boundaries. Of course, this requires high qualifications and special training of the interviewer for the study and subsequent formation of public opinion in order to effectively promote products. Accordingly, with the help of this technology, it is possible to build an advertising campaign in such a way that a potential consumer will necessarily buy products, and in this case high-tech offline marketing will give $100 \%$ results.

In addition, to date, there are new technologies of advertising and Internet marketing. Yahoo, Google, AOL have implemented a technology that tracks user requests in their search engines and, based on the data obtained about consumers, gives them advertisements of goods of interest to them. In this case, advertising ceases to be static, it becomes personalized, a person sees advertising only for those goods and services that interest him.

The French company Quividi introduced a technology that made an ordinary billboard reader. The latter, up to $85 \%$, determines the gender and age of a person who looks at the billboard and gives him an advertisement of interest.

If you combine, for example, Yahoo and Quividi technologies, you can get a combination of offline advertising and online marketing. Each particular person who looked at the billboard will be immediately "recognized", and on the banner will appear advertising of those products and services in which he was interested. And if you connect the American company Holosonic, which owns the technology of transferring sound to a clearly defined zone, to these two companies, it turns out that a 
The main approaches to the use of Internet marketing and advertising offline as a reflection of the interests of the subjects of advertising relations

The matrix forecast of the preferred types of marketing in the promotion of the main types of product groups *

\begin{tabular}{l|l|l|l}
\hline \multirow{2}{*}{ The target audience } & \multicolumn{3}{|c}{ Types of product groups } \\
\cline { 2 - 4 } & \multicolumn{1}{|c}{ Everyday goods } & \multicolumn{1}{c}{ Durable goods } & \multicolumn{1}{c}{ Subjects luxury } \\
\hline Youth (up to 30 years old) & Internet Marketing & Internet Marketing & Internet Marketing \\
\hline Average age & Offline marketing & Internet Marketing & Neuromarketing \\
\hline Retiree & Offline marketing & Online and offline marketing & Personalized advertising \\
\hline
\end{tabular}

Note: * - author's research

particular person will see and hear the advertisement, which will only concern him personally. It will be a fantastic breakthrough in marketing advertising technology. The consumer himself will regulate the quantity and quality of advertising and, as a result, it will become a point, narrowly targeted, unobtrusive, and most importantly - will reach one hundred percent of its target audience.

To ensure that the target audience is informed about specific product groups, it is logical to predict the alignment of forces by type of marketing in the next $2-3$ years. In Table we have developed and presented a matrix-forecast of the main marketing approaches that can be used in advertising the main types of product groups, based on the characteristics of the target audience.

For the "Youth" category, it is preferable to use Internet marketing, since this form of advertising strategy allows to take into account the fact that young people under the age of 30 spend on Internet services from 8 to 14 hours a day (according to official statistics), as determines the possibility of marketing communications with them mainly through the Internet space. In turn, this significantly narrows their perception of reality and does not allow the logical and accurate assessment of their daily needs. Internet advertising also becomes a priority when choosing a product group, which allows you to quickly assess and compare their advantages and disadvantages.

For potential middle-aged consumers, in the case of advertising of consumer goods, it is preferable to use offline marketing, since when choosing goods and services for everyday use, middle-aged people are more likely to buy promotional items, which make it possible to save a lot. In the case of durable goods and luxury goods, Internet marketing and neuromarketing will be the most optimal for the specified target audience, since middle-aged people get the maximum of necessary information about goods and services by viewing Internet news and advertisements "picked up" through spa programs (cookie files).

For the category "Retiree", consumer goods should be advertised through offline marketing, as older people are more inclined to believe advertising in newspapers and magazines, on posters of the market, and not on Internet advertising. Advertising of durable goods should be based on Internet and offline marketing, since the choice of this category of products begins to act the principle of «life experience», on which older people rely. As for luxury goods, the most appropriate marketing strategy should be personalized advertising, which opens up opportunities specifically and precisely to take into account the interests of the consumer, based on his personal priorities and socio-economic status, his ideas about luxury and ideas of the circle in which he rotates.

In our opinion, in the forecast period all types of advertising marketing strategies will be involved - both Internet and offline marketing, but with different intensity for different target audiences and product groups. The main task of advertisers will be a clear identification of the target audience on which to count, identifying potential access to the Internet, switching advertising to subjectivist orientation, developing ways of access of new advertising technologies to the most remote and limited in the Internet space consumer audiences. And then the promotion of goods and services will be extremely effective, help solve any problems with the sale of finished products and, as a result, give impetus to an increase in the volume of production of goods and services, as well as the realization of the interests of all parties of advertising relations. research

Conclusions and prospects for further scientific

Thus, with all the variety of types, methods (tools) and technologies for promoting the final product, the target function of any advertising strategy will be to achieve high efficiency and, consequently, increase net profit, sales, reduce costs, as well as meet the interests of consumers, advertisers and customers. These characteristics will be decisive when choosing the type of advertising in the medium term. At the same time, our proposed strategies for choosing marketing tools based on the structure of the target audience and the types of product groups will significantly increase the volume of sales and ensure its availability to the consumer. 


\section{REFERENCES}

1. Кузнєцова Н.. Інтернет-маркетинг в Україні: проблеми та перспективи // Вісник КНУ Шевченка. С. Економіка. - 2012. - № 137. - С.63-66

2. Ляшенко Г.П. Інтернет-маркетинг та його інструменти / Г.П. Ляшенко, Р.В. Моткалюк // Науковий вісник Національного університету державної податкової служби України. - 2013. - № 3. - С. 59-65

3. Мозгова Г.В. Інструменти Інтернет-маркетингу та їх переваги для сучасних українських підприємств [Electronic resource] / Г.В. Мозгова // Ефективна економіка. - 2013. № 10. - Access mode: http://www.economy.nayka.com.ua/ ?op $=1 \& \mathrm{z}=2429$

4. Сіденко Ю.В. Інтернет-маркетинг: переваги та недоліки / Ю. В. Сіденко // Матеріали XLVI науково-технічної конференції підрозділів ВНТУ, Вінниця, 22-24 березня 2017 p. - Електрон. текст. дані. - 2017. - Access mode: https:/ /conferences.vntu.edu.ua/index.php/all-fm/all-fm-2017/paper/ view/2718.

5. 17 эффективных методов оффлайн-рекламы [Electronic resource] - Access Mode: https:// partner.amarkets.org/17-effektivnyh-metodov-offlayn-reklamychast-1/

6. Интернет маркетинг - основы для новичков [Electronic resource] - Access Mode: http://business-ideal.ru/ internet-marketing

7. Плюсы и минусы криптовалюты [Electronic resource] - Access Mode: https://bitexpert.io/wiki/plyusy-i-minusykriptovalyuty/

Received 18.10.2018

Reviewer: Doct.Ec.Sc., prof. Tkachenko A.M.
Ключові слова: E-mail-маркетинг, вірусний маркетинг, Інтернет-реклама, персоналізована реклама, нейромаркетінг, онлайн-реклама, офлайн-реклама, економічні інтереси, рекламні відносини

\section{ОСНОВНЫЕ ПОДХОДЫ К ПРИМЕНЕНИЮ ИНТЕРНЕТ-МАРКЕТИНГА И РЕКЛАМЫ В ОФФЛАЙНЕ КАК ОТРАЖЕНИЕ ИНТЕРЕСОВ СУБЪЕКТОВ РЕКЛАМНЫХ ОТНОШЕНИЙ}

\section{Ищенко И. О., Смесова В.Л.}

Статья посвящена разработке основных подходов к применению Интернет-маркетинговых инструментов с иелью удовлетворения интересов субъектов рекламных отношений. Рассмотрены основные подходы для рекламы различных товарных групп в Интернет-пространстве в зависимости от иеле вой аудитории. Проанализированы слабые и сильные стороны онлайн- и офлайн-рекламы. Проведено сравнение различных инструментов Интернет-маркетинга - создание Веб-сайтов для презентации и продвижения своих товаров и услуг, E-таilмаркетинг, вирусный маркетинг. Рассмотрены экономические интересы каждой из сторон рекламных отношений. Предложена новая экономическая категория «симбион», под которой понимается форма рекламных взаимоотношений, при которых потенциальные заказчики рекламы удовлетворяют свои интересы при активном сочетании офлайн-рекламы с Интернетрекламой. Обоснованы основные экономические результаты взаимодействия офлайн-рекламы с Интернет-рекламой. Предложены новые инструменты рекламы - сбор индивидуальной информации о своих пользователях и персонализированная реклама, нейромаркетинг. Разработано и представлено матрииу прогноз основных маркетинговых подходов, которые могут быть использованы в рекламе главных видов товарных групп в зависимости от возрастной аудитории - для категорий «молодёжь», «люди среднего возраста», «пенсионеры».

Ключевые слова: E-mail-маркетинг, вирусный маркетинг, Интернет-реклама, персонализированная реклама, нейромаркетинг, онлайн-реклама, офлайн-реклама, экономические интересы, рекламные отношения.

\section{ОСНОВНІ ПІДХОДИ ДО ЗАСТОСУВАННЯ ІНТЕРНЕТ- МАРКЕТИНГУ ТА РЕКЛАМИ В ОФЛАЙНІ ЯК ВІДОБРАЖЕННЯ ІНТЕРЕСІВ СУБ'СКТІВ РЕКЛАМНИХ ВІДНОСИН}

Іщенко І.О., Смесова В.Л.

Стаття присвячена розробці основних підходів до застосування інтернет-маркетингових інструментів з метою задоволення інтересів суб'єктів рекламних відносин. Розглянуто основні підходи для реклами різних товарних груп в Інтернет-просторі в залежнності від цільової аудиторії. Проаналізовано слабкі і сильні сторони онлайн- і офлайн-реклами. Здійснено порівняння різних інструментів інтернет-маркетингу - створення Веб-сайтів для презентації і просування своїх товарів $i$ послуг, E-таil-маркетинг, вірусний маркетинг. Розглянуто економічні інтереси кожної зі сторін рекламних відносин. Запропоновано нову економічну категорію «сімбіон», під якою розуміється форма рекламних взаємин, за яких потенційні замовники реклами задовольняють свої інтереси при активному поєднанні офлайн-реклами з Інтернет-рекламою. Обгрунтовано основні економічні результати взаємодії офлайн-реклами з інтернет-рекламою. Запропоновано нові інструменти реклами - збір індивідуальної інформації про своїх користувачів $і$ персоналізована реклама, нейромаркетинг. Розроблено і надано матрицю-прогноз основних маркетингових підходів, які можуть бути використані в рекламі головних видів товарних груп в залежності від вікової аудиторії - для категорій «молодь», «люди середнього віку», «пенсіонери». 